\title{
APRESENTAÇÃO: DIREITO COLONIAL \\ NO MUNDO MODERNO
}

Carmen Alveal ${ }^{1}$

O dossiê Direito Colonial no Mundo Moderno apresenta um conjunto de artigos da área de História do Direito no período colonial do mundo ibero-americano. Estão presentes textos escritos por pesquisadores brasileiros e estrangeiros, historiadores e juristas. A intenção é fortalecer o diálogo entre essas duas ciências, ainda muito superficial na academia brasileira. A criação do Instituto Brasileiro de História do Direito, com seu congresso anual, tem tentado contribuir para essa aproximação, embora para o período em tela a participação ainda seja pequena. Por isso, a revista Fronteiras e Debates se regozija em oferecer esse dossiê temático, apresentando artigos significativos, que poderão contribuir para ampliarmos nosso conhecimento sobre o Direito no período moderno. Ainda há uma resistência grande por parte dos historiadores em se aprofundar nos textos jurídicos, sobretudo por resumirem estes materiais ao texto da lei. Ainda há que se ampliar essa compreensão para que o entendimento sobre direito não fique restrito às leis, mas inclua a literatura jurídica na sua forma mais ampla (doutrina, tratados, práticas, comentários, decisiones).

O primeiro artigo, escrito pelo professor do Departamento de Direito da Universidade Federal do Ceará Gustavo César Machado Cabral, analisa a obra de Antonil sob uma perspectiva raramente utilizada pelos pesquisadores: uma visão de um Antonil jurista, evidenciando os conhecimentos do jesuíta sobre o mundo do direito e sobre os juristas medievais e os do período moderno.

A obra de Juan de Solórzano Pereira, importante jurista espanhol e considerado o principal formulador do chamado Derecho Indiano, ainda pouco conhecido dos historiadores brasileiros, é analisado no artigo de Angela Ballone, historiadora do Max Planck Institute, da Alemanha. Ela aborda a importância de se conhecer a história da escrita, no sentido de perceber as diferenças de pensamento de uma obra para outra e os contextos de produção de cada uma.

\footnotetext{
${ }^{1}$ Doctor of Philosophy in History pela Johns Hopkins University (2007). Professora do Departamento de História da Universidade Federal do Rio Grande do Norte.
} 
A pesquisa de Sven Korzilius - estudioso da escravidão e pesquisador da Universidade de Ludwig-Maximilian também da Alemanha - em uma perspectiva de longa duração mostra as permanências e usos do ius commune, ou direito comum do continente, nos processos envolvendo escravos tanto em Portugal quanto na América portuguesa. Mostrando erudição sobre o direito comum, o autor explora os argumentos utilizados nas disputas judiciais.

Já o trabalho apresentado pela professora Márcia Motta, do Departamento de História da Universidade Federal Fluminense, retoma o debate entre dois grandes historiadores, os professores António Manuel Hespanha e Laura de Mello e Souza, acerca das relações de História e Direito, bem como discute alguns termos, como Antigo Regime para o caso das colônias do período moderno. Traz também para a discussão as ideias de Edward Thompson e Pierre Bourdieu.

A professora do Departamento de História da Universidade Federal Rural de Pernambuco Jeannie da Silva Menezes analisa, com base nos estudos dos historiadores americanos Jack Greene e John Elliot, a formação de tribunais ad-hoc numa tentativa de história comparativa entre os impérios português, espanhol e britânico. Discute também a questão da autonomia das agências coloniais frente à coroa portuguesa e como a questão do aparelho judicial era importante para a própria sustentação das áreas coloniais.

Por último, porém não menos interessante, o trabalho do doutor em História pela Universidade Federal Fluminense João Victor Pollig, aborda a Lei da Boa Razão, considerada fundamental para o estabelecimento de hierarquias das várias fontes do direito. Analisa a importância do comentário crítico publicado em 1824 pelo jurista José Homem Correia Telles para perceber o processo histórico de elaboração de Lei da Boa Razão.

Com esse conjunto de artigos, a revista Fronteiras e Debates procurou contribuir para ampliar o debate acerca das relações entre Direito e História, trazendo abordagens inovadoras e também estudos inéditos. Espera-se com isso destacar e reforçar a necessidade dos estudiosos da história do direito de mergulhar no Direito e também nas fontes que possam iluminar não somente como o direito era aplicado, mas como era pensado e percebido. Desejo a todos uma boa leitura. 